\title{
A Journey Into of the Universe of In Vitro Cultures of Plants. Callogenesis
}

\author{
Gogu Ghiorghiță \\ ${ }^{1}$ Academy of Romanian Scientists, Bucharest, Romania \\ Correspondence: Piatra Neamț, Aleea Plaiului 8/92, Romania. E-mail: g.ghiorghita43@gmail.com
}

Received: September 2, 2019

Accepted: November 22, 2019 Online Published: November 30, 2019

doi:10.5539/enrr.v9n4p45

\author{
URL: https://doi.org/10.5539/enrr.v9n4p45
}

\begin{abstract}
After presenting a brief history of the discovery of this system of cultivation of plant tissues and cells, of the evolution in time of knowledge in this field, of the pathways of in vitro morphogenesis in plants, the paper focuses on in vitro callogenesis in plants. There are presented the types of callus that can be generated via in vitro culture (illustrated with aspects from the author's experience), the influence of factors related to the biological nature of the explants, the composition of the nutrient medium, the cultivation conditions, etc., upon some characteristics of the callus obtained. A special chapter is dedicated to the importance of in vitro cultures of callus in plants.
\end{abstract}

Keywords: Plant Tissue and Cell Culture Brief History, In Vitro Callogenesis in Plants, Types of Callus, Importance of Callus Culture in Plants

\section{Introduction}

In vitro cultures of plants represent a system of cultivation of their specific organs, tissues and cells on artificial media containing all the necessary ingredients for plant growth and development, under aseptic conditions. Gautheret (1985) talks about a "prehistory of tissue cultures", which would have taken place more than 250 years ago, through the work of Duhamel de Monceau La Physique des Arbres, in which he discovered the formation of the callus in the trees, wound healing, sap circulation, etc. (David, 2017). The father of in vitro cultures, however, is considered to be the Austrian botanist Haberlandt, the first who advanced the idea and tried to cultivate leaf tissue fragments and other differentiated tissues of plants in the Knop culture medium, supplemented with sucrose. He managed to preserve the cells alive in the nutrient medium for about a month, while they increased in size and accumulated starch, but could not cause them to divide (Gautheret, 1985; Thorpe, 2007; Vaishnava, 2017; Hussain et al., 2012). In 1902, Haberlandt sent a report on his experiments to the German Academy of Sciences, accompanied by some comments on the impact of this type of research, among which a paragraph amazingly betrays his visionary spirit: "... I believe, in conclusion, that I am making too bold a prediction if I point to the possibility that, in this way, one could successfully cultivate artificial embryos from vegetative cells", a hypothesis that was to be confirmed in 1970 by Backs-Hüsemann and Reinert (Sussex, 2008). Haberlandt enjoyed an established reputation among botanists, especially after the publication in 1884 of the work "The Physiological anatomy of plants", in which he considered that anatomical investigations could obtain information regarding the relationship between the structure and functions of plant tissues (Noé, 1934). Although the experiments undertaken did not exceed a certain level of success, the observations made and his intuition led Haberlandt to formulate concepts that would be confirmed later: the concept of plant cell cultures and that of cellular totipotency; in other words, he envisaged the possibility of cultivation of artificial tissue fragments on artificial media and, respectively, that plant cells have the ability to grow into whole plants, just like a zygote (Toma et al., 2005; Thorpe, 2007; Vaishnava, 2017). In this area, similar to discovering new directions of research, the experiments in the field of in vitro cultures in plants have expanded, but it took more than three decades for progress to be registered. In 1934, White (cited by Sussex, 2008) obtained permanent root cultures of tomatoes in a liquid nutrient medium containing mineral salts, sucrose (2\%) and yeast extract (0.01\%). In 1934-1935, Gautheret made the first in vitro callus cultures on the aseptic medium, using small cambium and phloem explants of some tree species: Acer pseudoplatanus, Salix capraea, Ulmus campestre, Robinia pseudoacacia - inoculated on agarized Knop medium supplemented with glucose and cysteine hydrochloride.Callus cultures ceased growing after about 6 months of cultivation due to a deficiency in the nutrient medium, which was proven by Snow (1935) to be IAA auxin (Gautheret, 1985). Similar experiments were performed (in 1939) with cambial tissues grown on agarized 
Knop medium, supplemented with IAA (discovered by Went in 1926) and vitamins from group B, a medium on which both Gautheret and Nobécourt made in vitro carrot cultures for unlimited duration, including their differentiation, and White obtained callus cultures from tumour tissues of an interspecific tobacco hybrid (Nicotiana galucum x N. langsdorfii), (Gautheret, 1985; Sussex, 2008; Thorpe, 2007; Vaishnava, 2017; Kumar P.).

After the Second World War, the in vitro cultivation techniques of plant tissues, the composition of the nutrient media, the knowledge about the impact of growth and environmental factors on the evolution of plant explants etc., which allowed expanding the research area and approaching new directions of work in this field. Here are some landmarks of the progress made in this area in the years that followed, as recorded by some authors (Gautheret, 1985; Kumar S., a; Thorpe, 2007; Vaishnava, 2017; Hussain A. et al., 2012; Kumar P.). Caplin and Steward (1948) showed the effects of coconut water and 2,4-D on the proliferation of carrot and potato tissue cultures; Morel and Martin obtained in 1952 Dahlia plants free of viruses by in vitro cultivation of the apex of shoots (meristem cultures); Muir (1953) managed to obtain cell suspensions (which could be subcultured) in Tagetes erecta and tobacco from fragments of friable calluses inoculated on liquid media; Tulecke (1953) produced haploid callus from pollen in Gingko biloba; in 1955, Miller et al. discovered kinetin (a hormone involved in cell division), a cytokinin commonly used in in vitro cultures; in 1957, Skoog and Miller advanced a hypothesis (subsequently confirmed) that the in vitro rhizogenesis and caulogenesis process could be regulated by changing the ratio of cytokinins to auxins (a high ratio of auxins/cytokinins generally causes root generation, while a reverse ratio determines the generation of shoots); Cocking (1960) obtained protoplasts at Papaver rhoeas by enzymatic degradation of cell walls; in 1962, Murashige and Skoog developed a nutrient medium formula that was to become widely used in vegetable tissue cultures; in 1964, through in vitro culture of anthers, Guha and Maheshwari obtained the first haploid embryos at Datura innoxia; by fusion of protoplasts, in 1972, Carlson et al. obtained interspecific hybrids for tobacco, thus overcoming the reproductive barriers between species, whereas in 1978, Melchers et al., by the same process, obtained somatic hybrids between potato and tomato; it has also been observed that in plant cell cultures, genetic variations may occur, as evidenced and defined by Larkin and Scowcroft (1981) as somaclonal variability; in 1985, Horsch et al. regenerated Solanaceae plants genetically transformed by the infection of the leaf disks with Agrobacterium tumefaciens etc.

In the chapter "In vitro cultures of tissues and cells, a tool for manipulating the genome in plants", from a paper previously published by us (Ghiorghiță \& Petrescu-Nicuță, 2005), we presented extensively the technology of in vitro cultivation of plants, together with its theoretical and practical implications, therefore we will not insist on them in this article. We will briefly resume some aspects of the field, based on our personal experience and insist on calusogenesis (callogenesis) in in vitro cultures in plants.

\section{Pathways of in Vitro Morphogenesis in Plants}

The regeneration of organisms following injury or loss of a part of their body is a widespread phenomenon in the world of plants and animals and can take various forms, from the restoration (repair) of small lesions to the generation of new organs or individuals. Plants present at least two ways in the regeneration process: by reactivating undifferentiated cells and by reprogramming differentiated somatic cells (Ikeuchi et al., 2016).

Regeneration is also concerned when we refer to in vitro cultures in plants as a genetically-controlled phenomenon. In the paper published by us in 2005 (Ghiorghiță \& Petrescu-Nicuță, 2005), we showed that, depending on factors of internal nature - specific to the plant explant (the species and genotype to which it belongs, the stage of development of the plant donor of explants, the type of explant, the nature, the dimensions and its age, the level of ploidy etc.), but also on external factors (the composition of the nutrient medium, the quality and the quantity of the agar from the jellied media, the $\mathrm{pH}$ of the culture medium, the presence of growth factors in the nutrient medium, the incubation temperature of the culture vessels, the quality and light intensity in the culture chamber, the photoperiod, the oxygen gradient, the frequency of subcultures, the age of in vitro culture, etc.), the morphogenetic reaction and the explant evolution in in vitro culture may be different. It can follow the path of direct organogenesis or generate an undifferentiated tissue called callus, an amorphous mass of parenchymal cells (of different sizes, shape, appearance, colour, texture, proliferation rate, etc.), (Ghiorghiță \& Petrescu-Nicuţă, 2005). Of all the factors mentioned, the quality and the ratio between the growth regulators (between cytokinins and auxins in particular), included in the nutrient medium are those on which the in vitro evolution of the explants depends largely. In order to induce callus, the presence of auxins in the nutrient medium is necessary. They are involved in cell division and elongation, rhizogenesis, differentiation of vascular tissues, embryogenesis, inhibition of growth of axillary shoots etc. (Tavakkol-Afshari et al., 2011). 
In the case of direct organogenesis, the use as explants of shoots or uninodal fragments of shoots and their inoculation on suitable culture media - which include growth regulators in small quantities (in a certain cytokinin/auxin ratio) or in media in which these regulators are missing, the explants have the capacity to resume their growth, to generate axillary shoots or multiple shoots, to form roots and, finally, neoplantlets. It should be noted that, in some species, new plants were obtained in vitro and from leaf fragments and petioles etc. Direct organogenesis is the direct formation of explants of the shoots/stems (caulogenesis) and of the roots (rhizogenesis), a pathway commonly used in the clonal propagation of plants, an action that ensures the preservation of the biological material character of initiation of the in vitro culture. It is a method of multiplication that somewhat resembles the vegetative propagation (through cuttings, stolons, rhizomes, buds, etc.) characteristic of some plant species, except that it is produced under aseptic conditions in vitro and with a higher efficiency. The reaction of explants generating in vitro new plants depends primarily on the species in question. In many species, from explants such as shoots, uninodal fragments, etc., multiple common shoots are formed, but, in some shoots, they appear as rosettes, as we have observed in Digitalis purpurea (Ghiorghiță et al., 2002), or Chrysanthemum balsamita (Ghiorghiță et al., 2004). Usually, the shoots generate roots at the node in contact with the nutrient medium, but, in some species, along with these roots, the new plants form adventitious roots and at the upper nodes, a phenomenon observed by us in Stachys sieboldii (Ghiorghiță et al., 2000), Ocimum basilicum (Maftei et al., 2006) or Mentha piperita (Maftei, 2013).

During the in vitro culture in plants, the organogenesis can also follow the indirect pathway, the one in which the explant is first subjected to differentiation, generating an undifferentiated tissue - callus, which can then re-differentiate and form meristematic centers, by intervening in the composition of the nutrient medium and/or cultivation conditions (Ghiorghiță \& Petrescu-Nicuță, 2005). The callus tissue is heterogeneous, being made up of cells of different shape (from spherical to elongated), of various dimensions (from small cells to large cells). The small cells of the callus have a small vacuole, a dense cytoplasm and are actively divided, and the large elongated ones have a large central vacuole and do not divide. The latter can differentiate into tracheids or into phloem cells. Observations made by the electron microscope showed that, before the division, in the cells of the callus the amount of cytoplasm increases and the number of cellular organisms (mitochondria, Golgi bodies, endoplasmic reticulum, ribosomes), the cell wall is thin, and the microtubules are associated with the cell walls. In green-coloured areas, cells contain chloroplasts with poorly developed grana, plastids often functioning as amyloplasts (Kumar S., a). The growth rate of callus on the agarized medium is relatively low, and new cells are formed at the periphery of the callus mass, so that the callus tissue is made up of cells of different ages (Rai, 2007).

The callus tissue can have different reactions: it can multiply indefinitely, a quality that, in the case of friable callus, can be exploited to the purpose of obtaining biomass in suspension cell cultures or on solid media for the production of useful substances; it can differentiate into unipolar structures (the path of indirect organogenesis caulogenesis/rhizogenesis); it can generate bipolar structures (the pathway of somatic embryogenesis), which has unequivocally demonstrated cellular totipotency. In the mass of undifferentiated cells of the callus, the cyto-differentiation can take place, with the formation of organized structures, meristematic centers meristemoids. Meristemoids are made up of small cells with dense cytoplasm and prominent nuclei, they react to directional stimuli and will generate primordia from which sprouts or roots are born. There is a possibility that this callus will not differentiate and, with time, it will degenerate or, in the case of the friable one, as we mentioned before, it will proliferate indefinitely, given that certain cultivation conditions are met and it is subcultured at specific intervals. In some investigations, the level of some biochemical components in the differentiating and non-differentiating calluses was examined histochemically. In tobacco, for example, between the two categories of callus, there were no significant differences between the DNA/cell level; however, the amount of RNA and protein, but especially that of starch, were higher in the areas that generate shoots. Starch accumulation was considered to play a positive role in differentiating shoots (Thorpe and Murashige, quoted by Bhojwani and Razdan, 1996), a conclusion based on a series of observations upon which we do not insist.

In some plant species, the in vitro regeneration of new plants can occur in both pathways - both through organogenesis and somatic embryogenesis, but, in most plants, either one or the other of these pathways is specific. While in vitro organ regeneration is a unipolar phenomenon that requires two distinct induction signals - one for caulogenesis, the other for rhizogenesis, in the case of somatic embryos, which are bipolar, the induction signal is unique (Phillips, 2004).

In the last two decades, important progress has been made in identifying genes that control regeneration pathways (Ikeuchi et al., 2016) and morphogenesis (Phillips, 2004) in plants. Ikeuchi et al. (2016) approach regeneration as a larger phenomenon, which also includes in vitro regeneration in plants, a process intensified in this case by the 
contribution of growth factors in the nutrient medium. In the table below we present examples of genes involved in the processes of morphogenesis in plants.

Table 1. Examples of genes involved in plant morphogenesis (after Phillips, 2004, modified)

\begin{tabular}{|c|c|}
\hline Gene & Putative function \\
\hline \multicolumn{2}{|r|}{ Somatic embryogenesis } \\
\hline$L E C 2$ & Initiates ectopic somatic embryogenesis \\
\hline WUS (PGA6), SERK, LEC1 & Involved in the vegetative-to-embryogenic transition \\
\hline SHR & Establishes ground tissue via asymetric cell division \\
\hline$C L V, W U S$ & Regulate stem cell fate \\
\hline$C L V 1, C L V 3, S T M$ & Regulate shoot apical meristem development \\
\hline$L E C 1, F U S 3, A B I 3$ & Regulate embryo maturation \\
\hline \multicolumn{2}{|r|}{ Shoot organogenesis } \\
\hline CYCD3 & Involved in acquisition of competence for organogenesis \\
\hline SRD3 & Competence for shoot organogenesis \\
\hline$S R D 1, S R D 2$ & Competence for redifferentiation of shoots \\
\hline ESR 1 & Enhances shoot regeneration, vegetative-to-organogenic transition \\
\hline CRE1 & Cytokinin receptor \\
\hline$C K I I$ & Cytokinin perception \\
\hline$C L V, W U S$ & Preserve stem cell identity in shoot apical meristem \\
\hline$K N I, S T M$ & Initiate ectopic shoot meristem, shoot apical meristem function \\
\hline SHO, MGO & Modifiers of the shoot apical meristem involved in leaf founder cell recruitment, lateral organ primordial \\
\hline \multicolumn{2}{|r|}{ Root organogenesis } \\
\hline SRD2 & Competence for root organogenesis \\
\hline$P K L$ & Transition of embyonic root cells to grow vegetatively \\
\hline$R M L$ & Root apical meristem function \\
\hline CYCD4;1 & Involved in lateral root formation \\
\hline$R A C$ & Involved in adventitious root formation and auxin transduction \\
\hline
\end{tabular}

In a synthesis paper, citing a number of authors, Jiménez (2001) showed that somatic embryogenesis was described as the phenomenon by which somatic cells (haploids or diploids) develop in structures resembling zygotic embryos, passing through the embryological stages, characteristic, but not the result of the fusion of gamers. Somatic embryogenesis can be induced by many factors of stress such as salts, hypochlorite, osmotic pressure, heavy metal ions, temperature, cultivation on auxin-containing media and then transfer on the auxin-free media. Of the auxin-like substances, 2,4-D is one of the most efficient in this regard in many plant species, probably because 2,4-D "triggers both auxin and stress responses simultaneously" (Gliwicka et al., quoted by Ikeuchi et al., 2016).

Somatic embryos have continuous growth and lack vascular connections with parental tissues. The process consists of two phases: a) uniquely differentiated somatic cells become competent and evolve into "embryogenic cells" (the "induction" phase) and b) the embryogenic cells then turn into "somatic embryos" (the "expression" phase). Somatic embryogenesis can be direct, in the sense that somatic embryos can form in vitro on the surface of organized tissues (from somatic cells), and indirectly- when somatic embryos are derived from callus or from suspended cells. In general, the competent cells appear in the presence of auxin in the nutrient medium, and their embryogenic evolution takes place under the conditions of elimination or reduction of the auxin concentration in the culture medium. These cells resemble meristematic cells, form clusters, are isodiametric, have smaller dimensions, present nuclei and nucleoli that colour strongly and dense cytoplasm. The ontogeny of the somatic embryos is similar to the zygotic ones, passing through the globular stages, in the form of heart and torpedo to the dicotyledonous plants and respectively - globular, scutellar and coleoptilar to monocotyledonous plants (Jiménez, 2001). However, some differences exist between the two types of embryos. While the zygotic embryos, after the torpedo stage, evolve into the cotyledonary and maturation stage (when intense reserve protein synthesis takes place), followed by desiccation and dormancy, the somatic embryos grow and differentiate continuously (have no latency); that is why Zimmerman (1993) proposed for the fully differentiated somatic embryos the term "plantlet" embryo, as opposed to zygotic ones - "cotyledon" embryo. 
Without getting into other details, we will say that the induction and expression of somatic embryogenesis in vitro in plants depends on many factors: species, genotype, explant, treatments applied to explants before in vitro cultivation, composition of culture medium, cultivation conditions, etc. As already stated, an important role in this process lies with the growth regulators and especially auxins. Polar transport of auxin seems to be essential in establishing the bilateral symmetry of zygotic and somatic embryos, and to achieve this gradient, competent cells also require high levels of IAA. Molecular biology research aims to isolate and characterize genes involved in embryogenesis, as well as molecular markers for competent somatic embryogenesis cells (Jiménez, 2001). Somatic embryogenesis is used in the micropropagation of plants, regeneration of haploids and transgenic plants, for the study of fundamental processes regarding embryogenesis in plants (Filova, 2014; Rout et al., 2006).

\section{Callogenesis in Plants}

In a synthesis paper dedicated to this topic, Ikeuchi et al. (2013) showed that the term "callus" derives from the Latin "callum", by which it is initially called that formation generated in plants following the injury (of the bark in the case of trees). The callus appears, as we have shown above, as a tissue formation in traumatized areas of plants, with a role in wound healing. The lesion causes massive proliferation of cells (vascular, cortical or marrow cells) in the affected area and accumulation of chalice at the site of injury. Generating callus at the site of injury is actually a plant defense reaction, which protects them in this way from infection with pathogens. In this category, the generation of the callus at the sectioned ends of the fragments of organs grown in vitro and its induction under the action of growth regulators included in the nutrient medium enter the plants. It is interesting to know how the signals produced by the injury activate the cell proliferation and the generation of this undifferentiated tissue, an aspect addressed and discussed by Ikeuchi et al. in a synthesis paper published in 2017.

At present, the term callus has a broader meaning, by which it designates the generation of disorganized cell masses with indefinite growth. The induction of callus can also be determined by infection with pathogens (crown gall tumours in plants). Pathogens can be bacteria such as: Agrobacterium tumefaciens (best known and studied), Pantoea agglomerans pv gypsophilae, $P$. agglomerans pv betae, which produce the synthesis of auxins and cytokinins, or effector proteins that stimulate tumorigenesis. The production of plant tumours can also be induced by wound tumour viruses (WTVs) belonging to the family of Group III viruses, whose genome is made up of double-stranded RNA. The generation of gales can also be caused by some parasitic protists, nematodes and insects. Tumour formations may occur in plants as a result of interspecific crossings, a phenomenon observed in some species of Brassica, Datura, Lilium and Nicotiana (Ikeuchi et al., 2013).

The in vitro culture of callus also has a history. The first one who managed to obtain callus was Gautheret (1934-1937), by cultivating in a nutrient medium supplemented with vitamins and IAA the explants consisting of cambial willow tissue and other woody plants; later, Nobecourt (1939) obtained callus cultures from carrot roots, callus which on semi-solid medium had practically unlimited growth, if portions of it were transferred to fresh medium; Van Overbeck et al. (1941) showed that, in the cultures of callus, it is important to supplement the nutrient medium with coconut milk; later (1954-1955), Skoog obtained tobacco callus from root fragments inoculated on auxin-supplemented media and noted that its growth cessation could be canceled by kinetin supplementation of the nutritional medium; in 1957, Skoog and Miller established how the process of organ generation from callus can be controlled using plant hormones and suggested that the presence of $1 / 1$ ratio of auxin / kinetin in the nutrient medium causes the continuous growth of callus (Kumar S., b),etc.

In this paper, we will illustrate the comments and discussions on the callus with observations and photos taken in our Laboratory of tissue and plant cell cultures, in which we have conducted, over the years, investigations on a large number of plants (especially medicinal and aromatic plants), (Ghiorghiță et al., 1995, 1996, 1998, 2000, 2002, 2003, 20042005, 2006, 2007, 2009, 2011, 2012, 2015; Maftei et al., 2006; Nicuță et al., 2003, 2010, 2011, 2012, 2019; Prisecaru et al., 1995, 2002; Toma et al., 2005). The callus, as we have already shown, can be induced from any organ and young tissue of the plant grown in vitro: fragments of leaf, stem (uninodal or internodal), root, inflorescences, anthers, ovaries, etc., as it results from the photos below (Figure 1). 


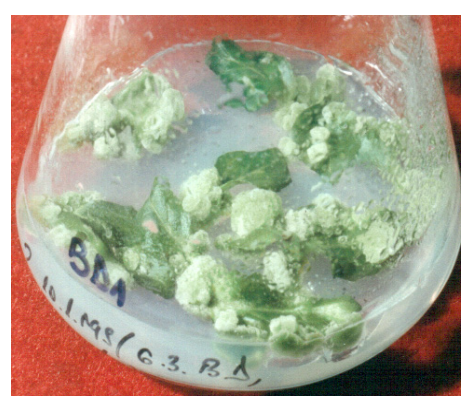

Callus from leaf - Ocimum basilicum,

(1 mg/l BAP + 0.5 mg/1 2.4-D)

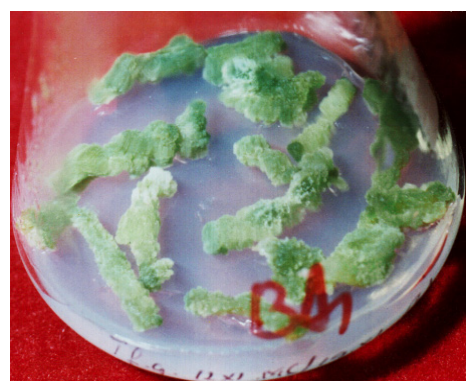

Callus from hypocotil - Trigonella foenum

graecum $(1 \mathrm{mg} / 1 \mathrm{BAP}+0.5 \mathrm{mg} / 12.4-\mathrm{D})$

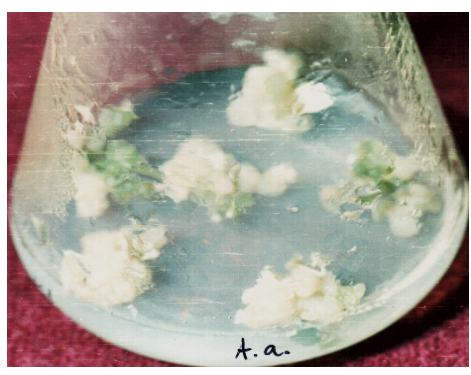

Callus from umbels - Angelica archangelica $(1 \mathrm{mg} / 1 \mathrm{BAP}+0.5 \mathrm{mg} / 1 \mathrm{NAA})$

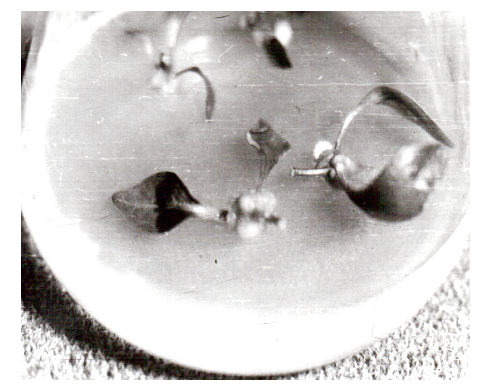

Callus from petiole - Vinca minor

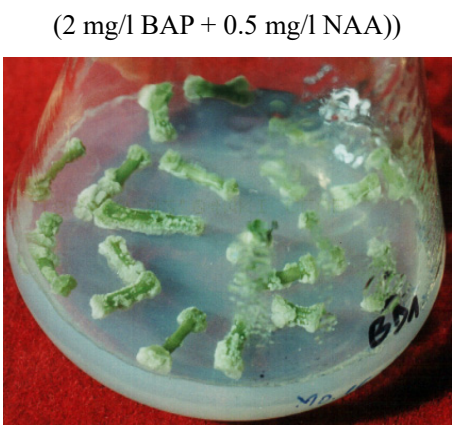

Internode callus - Mentha piperita

(1mg/1 BAP + 0.5 mg/1 2.4-D)

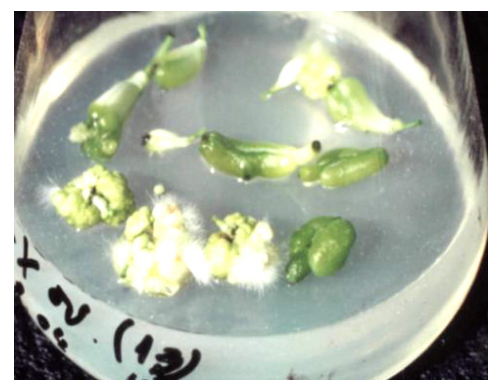

Calus from ovaries in broccoli

$(0.3 \mathrm{mg} / 1 \mathrm{BAP}+0.2 \mathrm{mg} / 12.4-\mathrm{D}+$

$0.1 \mathrm{mg} / 1 \mathrm{NAA})$

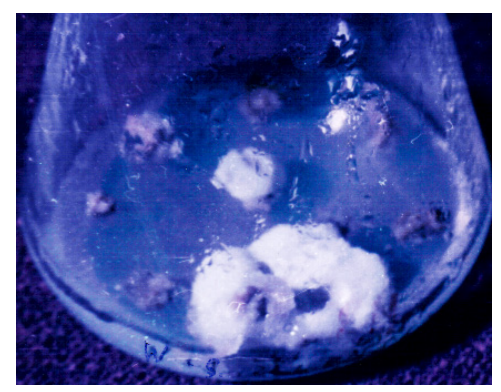

Node callus - Withania somnifera

(2 mg/1 BAP + 0.5 mg/1 2.4-D)

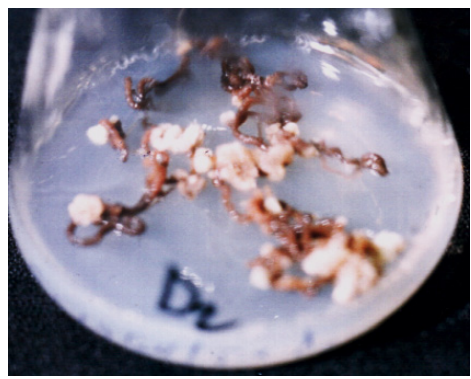

Callus from roots - Stachys sieboldii

(2 mg/1 2.4-D)

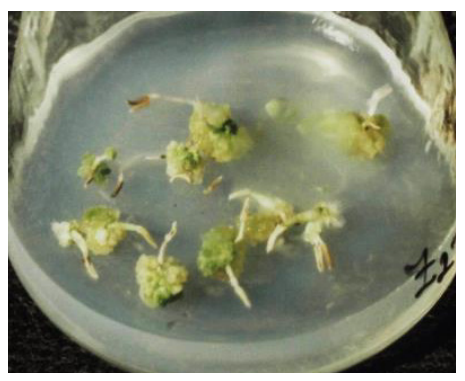

Anther callus - Brassica oleracea

$(1 \mathrm{mg} / 1 \mathrm{BAP}+0.5 \mathrm{mg} / 12.4-\mathrm{D})$

Figure 1. Callus obtained from various organs of plants

The passage of the callus at certain time intervals (depending on the species, explant, cultivation conditions, etc.) and its transfer to appropriate fresh media ensures its cell proliferation capacity. If the callus tissue is not subcultured in time, its viability decreases and its aging occurs, a phenomenon associated with colour change most often, its browning (Figure 2). Normally, the young callus has a creamy, green, creamy-green, yellowish, sometimes whitish colour; when it gets older, it becomes gray, reddish, yellow-brown, brown (Ghiorghiță \& Petrescu-Nicuță, 2005). 


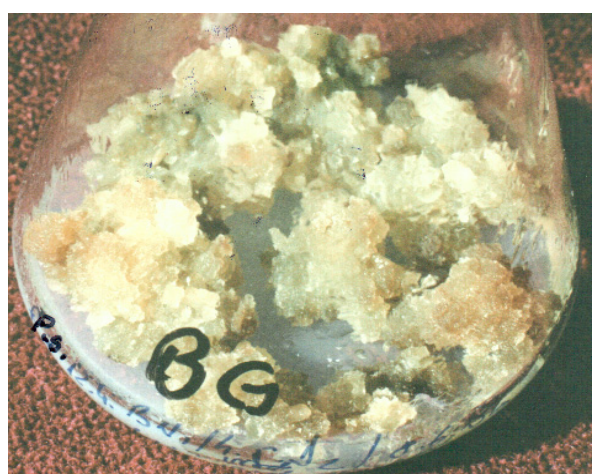

Callus from stem with high proliferation in Polymnia sonchifolia obtained on $2 \mathrm{mg} / 1$ 2.4-D medium and transferred on $1 \mathrm{mg} / 1 \mathrm{BAP}+0.5 \mathrm{mg} / 1 \mathrm{GA}$ medium

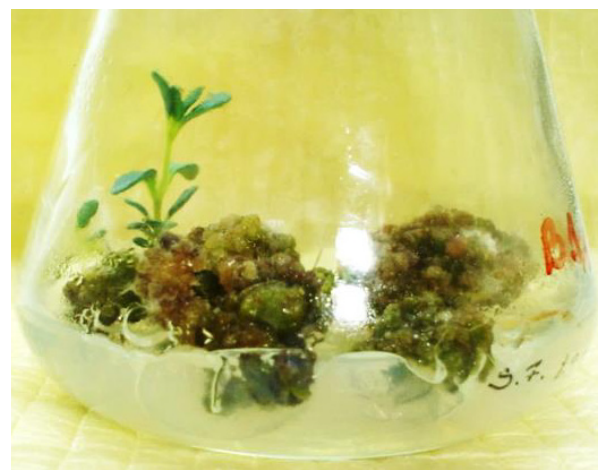

Callus from leaf aged at Sedum fabaria

$(1 \mathrm{mg} / \mathrm{l} \mathrm{BAP}+0.5 \mathrm{mg} / 12.4-\mathrm{D})$

Figure 2. Callus with intense proliferation (left) and callus aged (right)

The green callus grown in the dark is depigmented, but transferred to light, it regains its colour due to the development of chloroplasts (Figure 3). In the figure below, we show the aspect of the node callus obtained in Lavandula angustifolia on the culture medium supplemented with $2 \mathrm{mg} / \mathrm{l}$ IAA and subcultured in the dark for 19 passages on the hormone-free MS medium (left) and next to the same callus brought to light on a nutritional medium supplemented with kinetin and BAP (1/1), (Ghiorghiță et al., 2009).

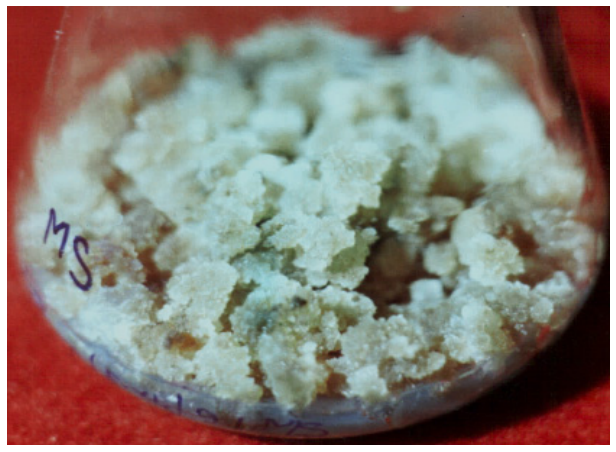

Node callus in Lavandula angustifolia cultivated in the dark (depigmented)

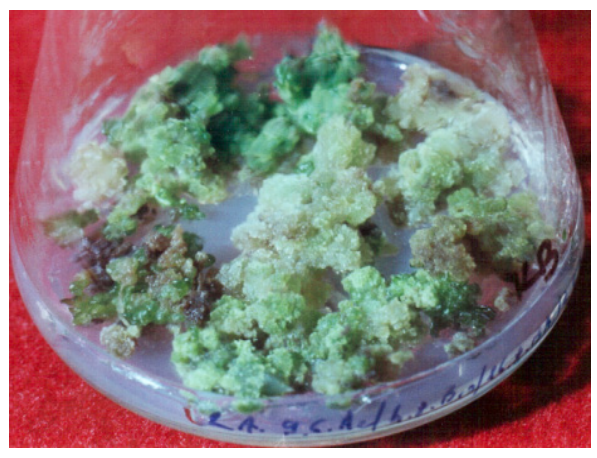

The same callus cultivated for light stage (regains its cream-greenish colour)

Figure 3. Callus grown in thea dark (left) and transferred to the light (right)

The yellow colour of some forms of callus would be due to the synthesis of carotenoid pigments, the purple colour would be due to the accumulation of anthocyanins or oxidized forms of DoPA in the vacuolar juice of the cells, and the brown colour to the excretion of some phenolic substances - which inhibit the growth of the callus (Kumar S., a).

Depending on the appearance, texture, origin, response in in vitro culture, etc., the callus tissue may vary within very wide limits. Thus, according to its texture (consistency) (Figure 4), the callus can be of two types: a) soft (friable)- a situation in which it consists of a heterogeneous mass of cells that can be easily separated (they have minimal contact between them); b) hard (compact), made up of large cells, closely connected to each other, of the tracheid type (Kumar S., a). In turn, the friable callus may have a coarse (crumbly) or foamy (lax) appearance. 


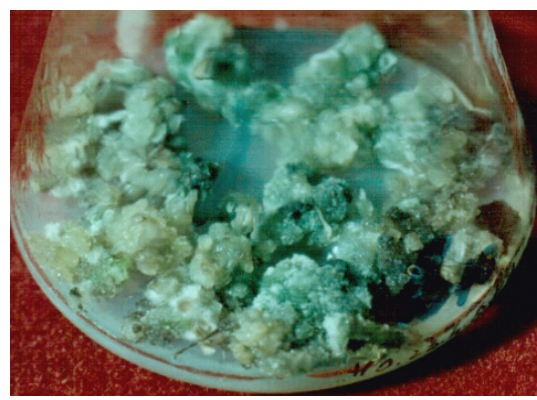

Hyssopus officinalis - friable (crumbly) node callus (on the medium with $2 \mathrm{mg} / 12.4-\mathrm{D}$ ))

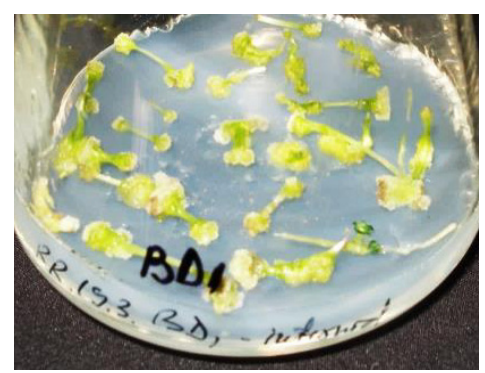

Rhodiola rosea - compact internode callus $(1 \mathrm{mg} / 1 \mathrm{BAP}+0.5 \mathrm{mg} / 12.4-\mathrm{D})$

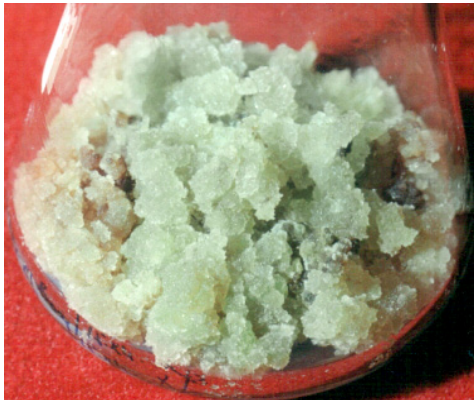

Lavandula angustifolia - foamy node callus

(on the medium with $2 \mathrm{mg} / \mathrm{l}$ IAA)

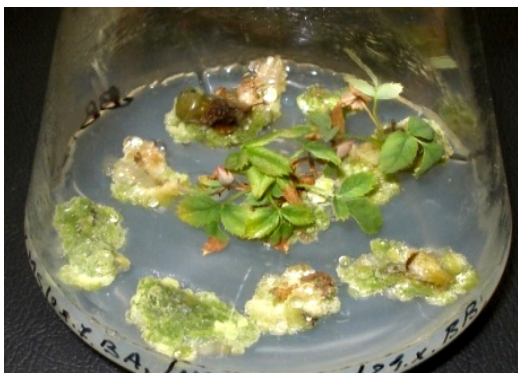

Rosa canina - compact node callus

$(1 \mathrm{mg} / 1 \mathrm{BAP}+0.5 \mathrm{mg} / \mathrm{IAA})$

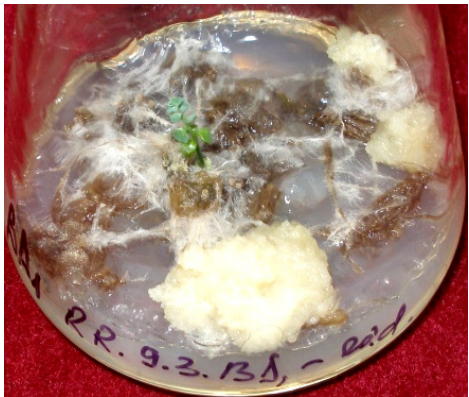

Rhodiola rosea - soft node callus

$(1 \mathrm{mg} / 1 \mathrm{BAP}+0.5 \mathrm{mg} / 12.4-\mathrm{D})$

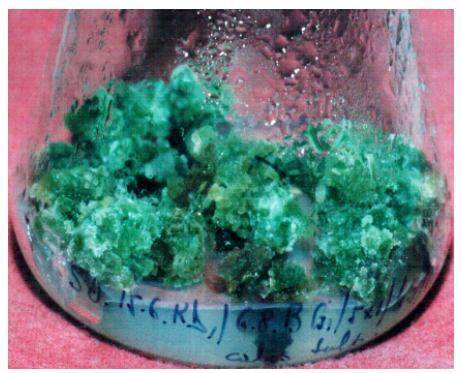

Salvia officinalis - semicompact leaf callus (1mg/1 Kin $+0.5 \mathrm{mg} / 1$ 2.4-D)

Figure 4. Types of callus according to its texture

Depending on its origin, the callus may be: a) primary - when formed on the initial inoculum, grown in vitro; b) secondary - when it comes from the sub-cultivated primary callus on a fresh nutrient medium (Figure 5).

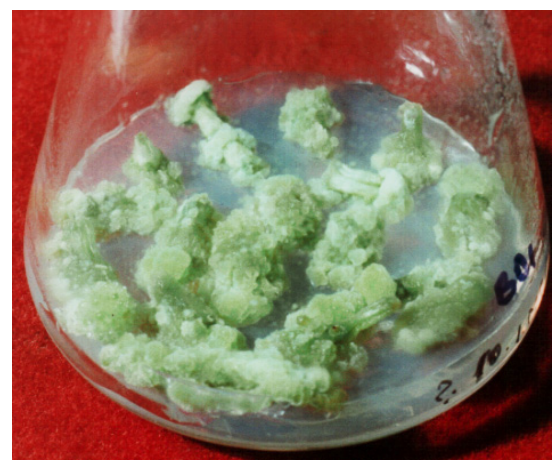

Ocimum basilicum - primary internode callus $(1 \mathrm{mg} / 1 \mathrm{BAP}+0.5 \mathrm{mg} / 12.4-\mathrm{D})$

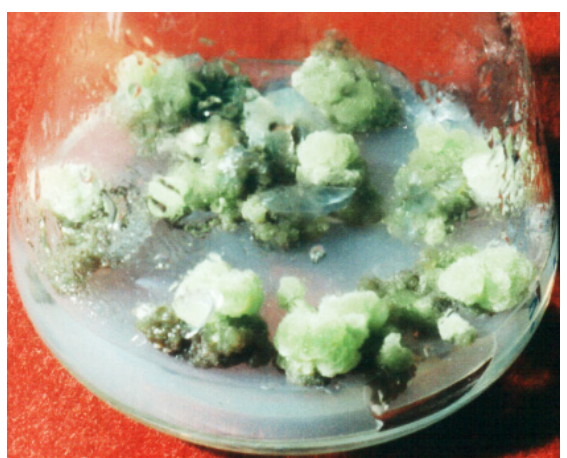

Ocimum basilicum - secondary internode callus $(0.2 \mathrm{mg} / \mathrm{BAP})$

Figure 5. Types of callus depending on its origin

Depending on the response in in vitro culture, the callus may be: a) regenerative or embryogenic- a situation in which it has the capacity to generate new plants; b) non-regenerative or non-embryogenic- when lacking this capacity (Figure 6). The embryogenic callus has a slow growth, is dense, translucent or opaque, has compact areas made up of undifferentiated cells that can generate embryos and new plants, is milky, yellowish or yellow-green in colour. The non-embryogenic one proliferates intensely, is looser (spreads easily in bundles of cells), is white, green or brown and does not generate new plants, but can sometimes form roots or (less rarely) buds (Cachiță-Cosma, 1987). 


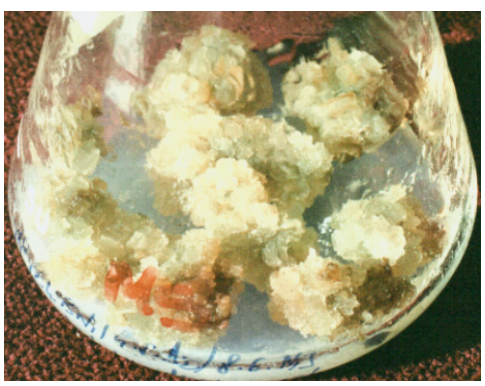

Digitalis purpurea - embryogenic callus from leaf (obtained on the medium with 2 $\mathrm{mg} / 1$ 2.4-D and transferred on MS without hormones)

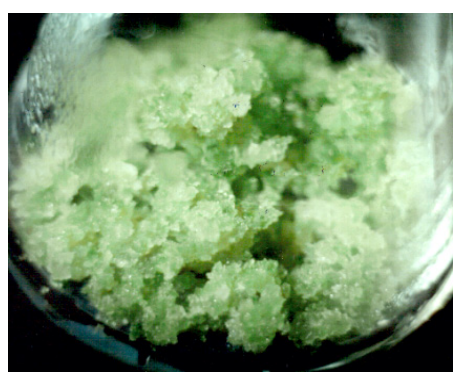

Polymnia sonchifolia-non-regenerative callus from leaf

$(1 \mathrm{mg} / 1 \mathrm{BAP}+0.5 \mathrm{mg} / 12.4-\mathrm{D})$

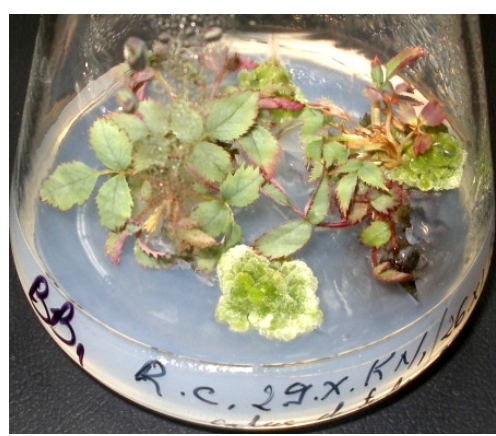

Rosa canina - organogenous callus (caulogen) of node $(1 \mathrm{mg} / 1 \mathrm{BAP}+0.5 \mathrm{mg} / 1 \mathrm{IBA})$

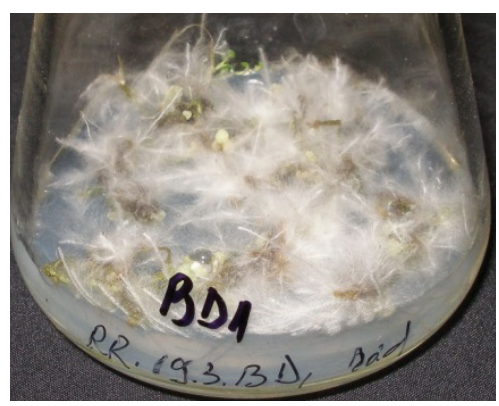

Rhodiola rosea - rhizogene callus from roots (1 mg/1 BAP + $0.5 \mathrm{mg} / 1$ 2.4-D)

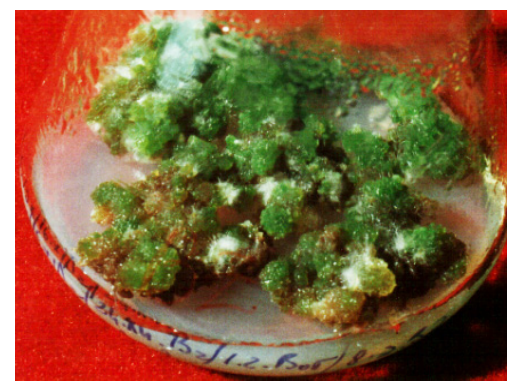

Digitalis purpurea - calus embriogen de

frunză transferat pe mediul cu 1 mg/l BAP

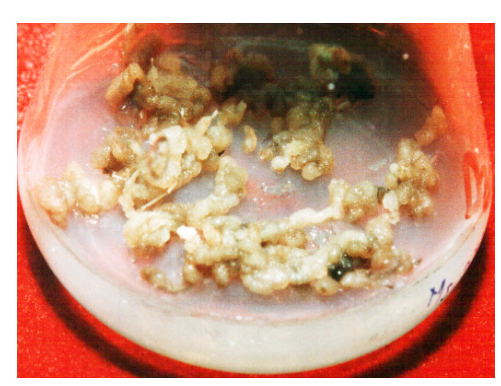

Mentha viridis-non-regenerative callus from roots obtained on the medium with $2 \mathrm{mg} / 1$ 2.4-D

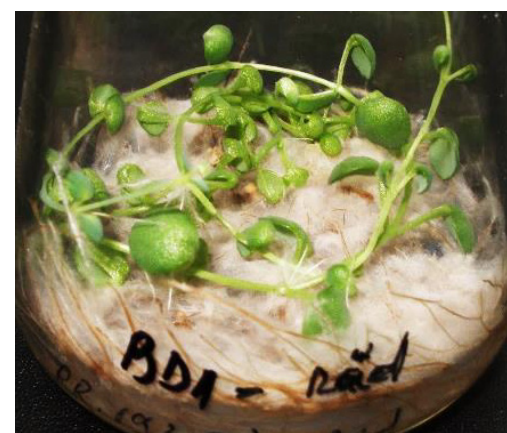

Rhodiola rosea- caulogen and rhizogene callus from roots

(1 mg/l BAP + $0.5 \mathrm{mg} / 1$ 2.4-D)

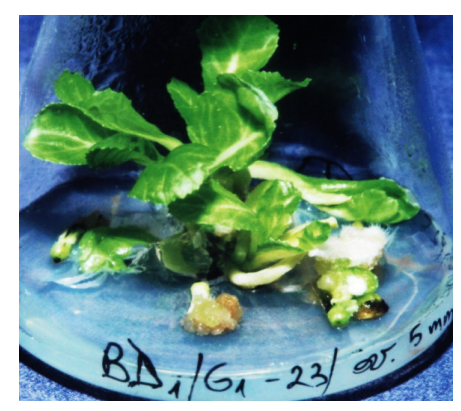

Brassica oleracea- caulogen callus from

ovaries(1mg/1 BAP + 0.5 mg/1 2.4-D)

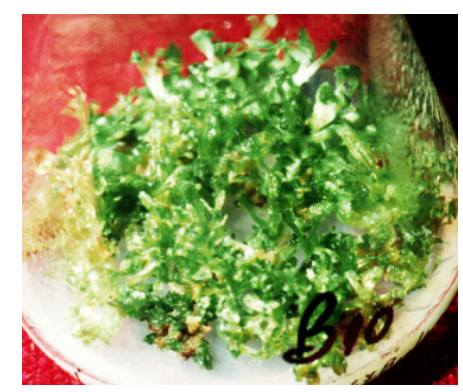

Digitalis purpurea- neoplantlets from

embryogenic callus from leaf obtained on the medium with $1 \mathrm{mg} / \mathrm{l} \mathrm{BAP}$

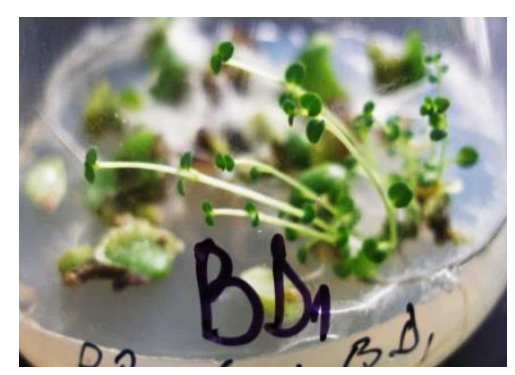

Rhodiola rosea- caulogen callus from leaves

$(1 \mathrm{mg} / \mathrm{l} \mathrm{BAP}+0.5 \mathrm{mg} / 12.4-\mathrm{D})$

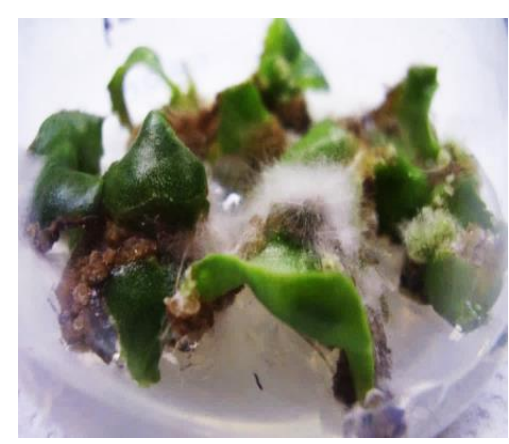

Sedum fabaria- organogenous callus (rhizogene) from leaves

$(1 \mathrm{mg} / \mathrm{l} \mathrm{BAP}+0.5 \mathrm{mg} / 12.4-\mathrm{D})$

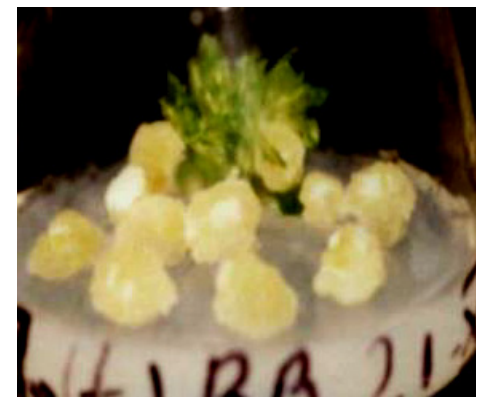

Brassica juncea- caulogen callus from anthers $(1 \mathrm{mg} / \mathrm{l} \mathrm{BAP}+0.5 \mathrm{mg} / 1 \mathrm{NAA})$

Figure 6. Types of callus depending on its response in in vitro culture 
We considered (Ghiorghiță \& Petrescu-Nicuță, 2005) that this equivalence regenerative = embryogenic and non-regenerative $=$ non-embryogenic is not exactly correct. The category of regenerative callus should also include the organogen one (which generates either shoots or roots), and the non-regenerative callus should be the one that does not generate new plants (through somatic embryogenesis), but neither shoots nor roots.

There are situations in which the callus tissue, obtained on a certain hormonal formula, can be subcultured and maintained for a long period in culture on the basic nutrient medium, without growth regulators. The phenomenon is called habituation and we found it in our investigations of the species Angelica archangelica and Lavandula angustifolia (Ghiorghiță et al., 1996; Ghiorghiță et al., 2009). The habituated callus differs from the ordinary one only in this respect. How the phenomenon of habituation is achieved is not exactly clear, but it is assumed that the callus tissue acquires the capacity to synthesize the growth regulators themselves necessary to perpetuate (Kumar S., a).

From our experience, we have found that the morphogenetic reaction of explants grown in vitro depends first and foremost on the specificity of the biological material. If in the case of some species we encountered the phenomenon of habituation of the callus, in the case of others -Sedum hybridum for example, the presence of auxins in the nutrient medium of the explants (uninodal segments of stem and shoots tips) did not induce the generation of callus, but of neoplantlets (Ghiorghiță et al., 2003). We have also observed that in the case of species such as Mentha viridis, M. piperita, Melissa officinalis, Chrysanthemum balsamita, Rosa canina and others which generates compact callus, its repeated subcultivation is a difficult process (Ghiorghiță et al., 2004, 2005, 2006, 2012), while in Digitalis purpurea and Lavandula angustifolia (which generates friable callus), the callus can be maintained in culture for a long time (Ghiorghiță et al., 2002, 2009). While in some species such as Angelica archangelica the induction of caulogenesis via callus has been a difficult phenomenon (Ghiorghiță et al., 1996), in Digitalis purpurea and Lavandula angustifolia, it has been very effective (Ghiorghiță et al., 2002, 2009). The preservation of the caulogenetic capacity of the callus varies depending on the species: if in species such as Rosmarinus officinalis, Rosa canina, etc., the callus loses its property after a few subcultures (Prisecaru et al., 1995; Ghiorghiță et al., 2012), in Lavandula angustifolia, it was maintained even after 20 successive subcultures (every 3-4 weeks), (Ghiorghiță et al., 2009). It should also be noted that the callus tissue has great variability and, sometimes, at the same plant and in the same type of explant, a different callus can be generated in terms of texture, colour, proliferation and regenerative capacity, etc.

As it turned out from our investigations, but also from the works of other authors (Ali \& Iqbal, 2012; Bosila et al., 2003; Burbulis et al., 2007; Fatima et al., 2009; Kumar S. a; Polanco et al., 1988; Verma et al., 2016), the qualities of the callus obtained in in vitro culture (texture, colour, speed of cell proliferation, content in certain substances, etc.), its subsequent evolution, biomass production, etc., depend on many factors, such as: the species, the genotype of the plant, the type of explant, its age, the composition of the nutrient medium, the growth regulators present in the culture medium (the type, concentration and ratio between them, in vitro cultivation conditions (light/dark, photoperiod, light quality and intensity, temperature) etc.

\section{The Importance of Callus Cultures}

\subsection{Obtaining New Plants by Indirect Organogenesis or Somatic Embryogenesis}

Due to the cellular totipotency, by manipulating the concentration and the ratio between the growth regulators in the nutrient medium and the culture conditions, the differentiation of the callus cells can be induced organogenesis (with the generation of meristematic centers and formation of primordia of shoots/roots) or somatic embryogenesis (bipolar structures similar to zygotic embryos), as we mentioned earlier. Although things are a bit more complex, it can be appreciated that, in general, by manipulating the relationship between cytokinins and auxins in the culture medium, the process of differentiation of the callus, with the non-organ formation, can be guided, as follows: a high level of cytokinins and low auxin induces caulogenesis (generation of shoots); a favorable auxin ratio induces rhizogenesis (root generation); at an intermediate ratio between cytokinins and auxins, the perpetuation and proliferation of the callus is ensured. It should be noted, however, that the specificity of the biological material plays a very important role in these reactions of the callus. Transferring the shoots and rooting them on suitable nutrient media (higher level of auxins, or lacking phytohormones) ensures the obtaining of neoplantlets.

If indirect organogenesis, via callus, is a widespread phenomenon in in vitro culture in plants, somatic embryogenesis is somewhat narrower, has a higher specificity. Although we have worked on a large number of species, we have only succeeded in inducing somatic embryogenesis in the species Digitalis purpurea (Ghiorghiță et al., 2002). Somatic embryogenesis can be initiated directly from explants, or indirectly via callus (Hussain A. et al.). As we have already shown, somatic embryogenesis can be induced under stress conditions, by culturing the 
cells on a nutrient medium supplemented with auxins and subsequently transferring them to media lacking auxin. 2,4-D acid is an efficient inducer of somatic embryogenesis in many plant species, being both a stress factor and having an auxin effect (Ikeuchi et al., 2016). Indirect organogenesis via callus and somatic embryogenesis are two ways in which in vitro plant multiplication can be ensured. In this case, however, it is not a clonal propagation, as in the case of direct organogenesis, because the cells of the callus may contain a series of genetic variations that will manifest in the regenerants.

\subsection{In Vitro Cultures in Plants, a Source of Genetic Variability}

In the somatic cell cultures in plants, there occurs a certain chromosomal instability (Sunderland, 1973). In a previous paper (Ghiorghiță \& Petrescu-Nicuță, 2005), we dedicated a special chapter to the genetic variations that occur in in vitro cultures of plants, called somaclonal variation (Larkin \& Scowcroft, 1981), in which we presented a series of information on the manifestation forms of these variations, some of their causes, examples of variations found in callus cultures and in regenerants etc., and we showed that they represent a new source of genetic variability that can be speculated in plant melioration. It is considered that some of the variations exist in the explant, that the cytogenetic state of the in vitro cells depends on the cultivation conditions, that in the callus cultures a chromosome instability occurs, that with the increase of the cultivation duration (with the age of the culture) the chromosomal variations are amplified, that in in vitro cell cultures some transposable elements could be activated etc. (Lee \& Phillips, 1988). Somaclonal variation seems to be influenced by plant genotype, source of explants, donor plant age, in vitro culture conditions (Jain, 2001).

In Allium sativum, Novák (1981) noted a progressive reduction in the number of diploid cells and an increase in the number of polyploid cells, as the age of the callus originated from apical meristems or leaves increases. The author considers that genotype and partially culture conditions (especially growth regulators) can influence the cariological constitution of the proliferating cell population. The clones regenerated from these two types of callus were 55.4\% diploid, 2.2\% tetraploid, $10.6 \%$ aneuoploid and 31.8\% mixoploid (Novak, 1980). Plants regenerated after 32 weeks of organogenic callus from maize embryos (subcultured for 84 months), showed genomic mutations of the type of aneuploidy and tetraploidy, chromosomal restructuring such as deficiencies, duplications, inversions, translocations, chromosomes in the ring, and those regenerated 64-84 weeks of age were sterile (Molina \& Garcia, 1998).

In differentiated tissues of plants, endoreduplication is a frequent phenomenon, and its level depends on the degree of cell differentiation. In explants used to induce callus, there is a certain degree of genomic heterogenity of cells, which may be the source of variation in callus tissue, so that callus cells may have sets of chromosomes ranging from aneuploidy to different levels of polyploidy. These variations in the number of chromosomes in the callus cells may increase or decrease through successive subcultures of the callus. Structural-chromosomal changes, such as deletions, translocations, etc. can also occur in callus cultures. Some of the anomalies mentioned may pre-exist in explants, others may be due to mitotic disorders caused by growth regulators (Kumar S., a).

Our investigations on callus cells from ovaries in Triticum aestivum revealed the presence of diploid and haploid cells, and of some aneuploid cells in the case of Solanum tuberosum. Cytogenetic analyses performed on regenerants derived from ginogenetic callus in the two species, such as Beta vulgaris and Heliathus annuus, identified haploid, diploid and mixoploid metaphases. In the case of the Beta vulgaris species $(2 \mathrm{n}=18)$, tetraploid metaphases were identified, and aneuploid metaphases for the Solanum tuberosum species (Prisecaru \& Ghiorghiță, 2002). In the cytogenetic observations made by us on regenerants from the anthers and ovaries in Brassica oleracea and B. juncea, we have shown a high frequency of chromosomal abnormalities in the ana-telophases (AT) of radicular meristems, consisting of: AT with chromatidal and chromosomal bridges (simple or multiple), AT with delayed or expelled chromosomes, AT with micronuclei and fragments, AT with complex aberrations, AT in which the genetic material is unevenly separated, disorganized AT, etc. Cytogenetic changes were observed in both species and in other phases of the mitotic cycle: interphase, prophase or metaphase. Cytophotometric analyses on anthers and ovarian regenerants in $B$. oleracea showed that the majority were mixoploids (with cells $2 \mathrm{C}, 4 \mathrm{C}$ and $8 \mathrm{C}$ ), only one vitroplant (obtained from the ovaries) being tetraploid. At $B$. juncea, the analysed regenerants were haploid (Nicuță et al., 2012; Nicuță \& Ghiorghiță, 2019).

\subsection{Callus Cultures in Plants - Source of Secondary Metabolites}

In vitro tissue cultures in plants have opened a new perspective in obtaining unconventional by-products of necessary metabolism products in some industries, such as pharmaceuticals, cosmetics, etc. The use of callus cultures in the production of secondary metabolites in plants has a number of advantages over conventional cultures: 
- compounds of interest can be obtained under controlled conditions, independent of environmental and soil factors;

- in vitro cultures prevent the attack of harmful microbes or insects;

- the cells of any plant, even the rare or endangered ones, can be multiplied in vitro to obtain specific secondary metabolites;

- the processes of growth and production of metabolites can be controlled automatically, which causes the cost price reduction and increases the productivity (Efferth, 2019; Hussain S. et al., 2012).

In general, the presence of secondary metabolites is related to the processes of cell differentiation and, for this reason, not all species of medicinal plants used in the conventional production of secondary metabolites produce these metabolites in cultures of callus cultures or in suspension cell cultures. Here are some examples of species in which callus cultures produce compounds of interest, specific to some plants. Panax species have been the subject of such concerns, due to their content in ginsenosides (triterpene glycosidic saponins), substances with strong immunomodulatory, adaptogenic and aphrodisiac actions. Panax ginseng callus has been found to produce the same types of saponins in large quantities as the intact plant. The content of these compounds decreases in habituated callus compared to normal callus (Furuya et al., 1983). Cultures of callus or suspension cells of $P$. quinquefolium produced a maximum level of compounds in the $\mathrm{Rb}$ group after 25 days of cultivation, and for compounds in the Rg group after 30-35 days of cell culture in suspension (Mathur et al., 1994). Investigations conducted on three Panax species, have reported that the highest level of ginsenoside $(0.56 \%$ f.wt. $)$ was reached in the callus cultures of $P$. quinquefolium after 5 weeks of cultivation, whereas for $P$. pseudoginseng $(1.10 \%$ f.wt $)$ and P. sikkimensis ( $0.96 \%$ f.wt), after 7 weeks of cultivation (Mathur et al., 2000).

Callus cultures from Stevia rebaudiana leaves produced the highest amount of biomass on MS medium supplemented with a combination of 2,4-D, NAA and Kn, steviosides being present in large quantities in undifferentiated cells (Janarathanam et al., 2010). Callus cultures in Charybdis congestive obtained on MS medium supplemented with NAA and BAP produced large amounts of active principles (even higher than in the intact plant): proscillaridin A ( $4.51 \mathrm{mg} / \mathrm{g}$ d.wt.), scilliroside $(3.3 \mathrm{mg} / \mathrm{g} \mathrm{d}$.wt.), scillaren A ( $2.35 \mathrm{mg} / \mathrm{g} \mathrm{d} . \mathrm{wt}$.) and deacetylscilliroside ( $8.62 \mathrm{mg} / \mathrm{g}$ d.wt.), (Reddy et al., 2013). The callus of Pueraria candollei var. mirifica, from strain explants, grown on MS medium supplemented with TDZ $(0.5 \mathrm{mg} / \mathrm{l})$, produced a high level of isoflavonoids $(50.39 \mathrm{mg} / \mathrm{g} \mathrm{d} . w \mathrm{t}), 7$ times higher than in native tuber (Udomsuka et al. 2009). Callus cultures from Pluchea lanceolata leaves on MS medium supplemented with BAP and NAA recorded the highest quercetin content $(0.23$ $\mathrm{mg} / \mathrm{g} \mathrm{d.wt}$.) at 6 weeks of age (Arya et al., 2008). The callus obtained from leaf explants, grown on MS medium supplemented with BA and 2.4-D, achieved the best biomass production and had a high alkaloid content (Verma et al., 2012). Extensive information on the achievements in the field of callus cultures as biological material for obtaining by-products of metabolism can be found in two synthesis papers published by Filová (2014), and Efferth (2019).

The callus cultures that produce certain secondary metabolites are also important as a source for obtaining these metabolites in cell suspension cultures in bioreactors, following the model of microorganisms. In this case, friable callus portions capable of the synthesis of such compounds, are transferred to bioreactors of various sizes, in liquid nutrient medium, where the culture conditions (aeration, light, temperature, $\mathrm{pH}$, medium composition, etc.) are automatically controlled and regulated. Interesting results in this respect were obtained in species such as: Lithospermum erythrorhizon, Coptis japonica, Catharanthus roseus, Digitalis lanata, Dioscorea deltoidea, Panax notoginseng, Taxus wallichiana, Maackia amurensis, Hypericum perforatum, Sophora flavescens etc. (Filova, 2014). Although many species of medicinal plants (of the order of hundreds) have the ability to synthesize specific secondary metabolites in this culture system, the commercial production of some of them is restricted to only a few, namely: shikonin, scopolamine, protoberberines, rosmarinic acid, paclitaxel, echinaceae polysaccharides, ginsenoside saponins (Yue et al., 2014). We do not intend to develop this topic here, since in a previous paper, we dedicated a special chapter to the cell suspension cultures, the best achievements in this culture system, the field perspectives, including information on the use of these cultures in the biotransformation reactions of some precursors in metabolites of interest (through hydroxylation, glycosylation, acetylation or methylation reactions), increasing the efficiency of cell biosynthesis by using elicitors, the use of immobilized cells on various supports, etc. (Ghiorghiță \& Petrescu-Nicuță, 2005). Extensive and interesting information on the achievements in the in vitro production of secondary metabolites in tissue cultures, organs and cells in suspension in medicinal plants by various authors, can also be found in two synthesis papers on this subject published by Vanisree et al. (2004), and Karuppusamy (2009). 
Despite the fact that the number of works in the field of in vitro plant cultivation has declined in the last two decades, the potential of this field cannot be underestimated. In addition to the advantages outlined above, we can add the cloning and micro-propagation of plants, obtaining of plants free of viruses, of protoplasts and somatic hybrids, of haploids and, implicitly, of isogenic lines, etc., which entitles us to believe that in vitro cultures in plants will continue to be used in the future to achieve some of these goals.

\section{Conflict of interests}

The authors declare that there is no conflict of interests regarding the publication of this paper.

\section{References}

Ali, S., \& Iqbal, J. (2012). Influence of physical factors on callogenesis in sugarcane (Saccharum officinarum L.). Sci. Int. (Lahore), 24(2), 167-170.

Arya, D., Patni, V., \& Kant, U. (2008). In vitro propagation and quercetin quantification in callus cultures of rasna (Pluchea lanceolata Oliver \& Hiern). Indian J. Biotechnol., 7, 383-387.

Bhojwani, S. S., \& Razdan, M. K. (1972). Plant tissue culture: Theory and Practice. Elsevier, 1996.

Bosila, H. A., Mohamed, S., Gamal, S. El., \& Bekhit, M. (2003). Factors affecting callus production and glycosidal content of leaf tissue culture of Digitalis lanata Ehrh. Proceed. Int. Conf of MAP, Eds. Bernath et al. Acta Hort., 597.

Burbulis, N., Blinstrubiene, A., Sliesaravicius, A., \& Kupriene, R. (2007). Some factors affecting callus induction in ovary culture of flax (Linum usitatissimum L.). Biologija, 53(2), 21-23.

Cachiță-Cosma, D. (1987). Metode in vitro la plantele de cultură. Edit. "Ceres". București, 274.

Carlson, P. S., Smith, H. H., \& Dearing, R. D. (1972). Parasexual interspecific plant hibridization. Proceed. Nat. Acad. Sci. (USA), 69, 2292 - 2294.

Cocking, C. E. (1960). A method for the isolation of plant protoplats and vacuoles. Nature (London), 187, 927-929.

Efferth, Th. (2019). Biotechnology applications of plant callus cultures. Engineering, 5(1), 50-59.

Fatima, Z., Mujib, A., Fatima, S., Arshi, A., \& Umar, S. (2009). Callus induction, biomass growth, and plant regeneration in Digitalis lanata Ehrh: Influence of plant growth regulators and carbohydrates. Turk. J. Bot., 33, 393-405.

Filova, A. (2014). Production of secondary metabolities in plant tissue cultures. Res. J. of Agric. Sci., 46(1), 236-245.

Furuya, T., Yoshikawa, T., Ishii, T., \& Kajii, K. (1983). Regulation of saponin production in callus cultures of Panax ginseng. Planta Medica, 47(4), 200-204.

Gautheret, R. J. (1985). History of plant tissue and cell culture: A personal account. In I. K. Vasil (Ed.), 2. Cell growth nutrition, cytodifferentiation and cryopreservation (pp. 2-60). Acad. Press Inc., Orlando, Florida.

Ghiorghiță, G., \& Petrescu-Nicuță, D. (2005). Biotehnologiile azi. Edit. Junimea. Iași, 326.

Ghiorghiță, G., Gille, E., \& Nicuță, D. (2002). Considerations on the in vitro behaviour of Digitalis purpurea L. species. Proceed. 2-nd Internat. Symp. Genetic engin. and modern biotechnol. Chisinau, 24-25, 202-209.

Ghiorghiță, G., Gille, E., Nicuță, D., \& Hârțan, M. (2003). Some considerations on in vitro and ex vitro behaviour of Sedum hybridum species. Revista medico-chirurgicală, 107(2), 63-72.

Ghiorghiță, G., Gille, E., Prisecaru, M., Nicuță, D., \& Pîslariu, C. (1998). Aspects of in vitro behaviour of Withania somnifera Dun. I. Callus and organogenesis induction. St. şi Cercet. Șt., Ser. Biol. (Univ. Bacău), 3, 113-120.

Ghiorghiță, G., Hârțan, M., \& Hăncianu, M. (2007). Some aspects concerning the in vitro reaction of Sedum fabaria Koch species. Europ. J. of Drug Metabolism and Pharmacokinetics., 32, 15.

Ghiorghiță, G., Hârțan, M., Maftei, D. E., \& Nicuță, D. (2011). Some considerations regarding the in vitro culture of Rhodiola rosea L. Romanian Biotechnological Letters, 16(1), 5902-5908.

Ghiorghiță, G., Ionică, D. E., Toma, I., \& Nicuță, D. (2004). Observations on the in vitro and ex vitro behaviour of Chrysanthemum balsamita L species. An. Șt. Univ. “Al. I. Cuza” Iași, Ser. Genet. și Biol. Mol., 5, 232-239. 
Ghiorghiță, G., Lazurcă, D., Gille, E., \& Prisecaru, M. (1996). Inducerea calusului in vitro la Angelica archangelica, Acta Phytotherapica Romanica, 3(1-2), 43-45.

Ghiorghiță, G., Maftei, D. E., \& Nicuță, D. (2009). Some aspects concerning the in vitro reaction of Lavandula angustifolia L. Propagation of ornamental plants, Sofia, SEJANI Publ., 9(1), 47-49.

Ghiorghiță, G., Maftei, D. E., \& Nicuță, N. D. (2005). Investigations on the in vitro morphogenetic reaction of Melissa officinalis L. species. An. Șt. Univ. “Al. I. Cuza” Iași, Ser. Genetică și Biol. Mol., 5, 119-125.

Ghiorghiță, G., Maftei, D. E., Gille, E., \& Nicuță, D. (2006). Morphogenetical and biochemical studies of Mentha viridis L. in in vitro cultures. Proceed. 3-rd CMAPSEEC, Belgrade, Serbia, 54-58. ISBN: 86-909717-0-X.

Ghiorghiță, G., Maftei, D. I., \& Maftei, D. E. (2015). Rhodiola rosea L. - a valuable plant for traditional and for the modern medicine. An. Șt. Univ. "Al. I. Cuza” Iaşi, s.II.a. Biol. Veget., 61(1-2), 5-25.

Ghiorghiță, G., Maftei, D. I., Nicuță, D., Maftei, D. E., \& Bădăluță, N. (2011). The study of several morpho-physiological indices of in vitro regenerants of Rhodiola rosea L. and Stachys sieboldii Miq. An. Șt. Univ. “Al. I. Cuza” Iaşi, Ser. Biol. Veget., 57(2), 53-60.

Ghiorghiță, G., Nicuță, D., Maftei, D. E., \& Maftei, D. I. (2012). Preliminary data of the in vitro culture response of Rosa canina L. species. An. Şt. Univ. “Al. I. Cuza” Iaşi, Ser. Genet. şi Biol. Mol., 13(2), 67-72.

Ghiorghiță, G., Nicuță, D., Mireanu, S., \& Ionică, D. E. (2003). Observations on in vitro behaviour of the species Brassica juncea Czern. An. Șt. Univ. Al. I. Cuza” Iaşi, Ser. Genetică şi Biol. Mol., 4, 81-88.

Ghiorghiță, G., Prisecaru, M., Mireanu, S., \& Bodrug, M. (1995). Aspecte ale comportării in vitro la Stevia rebaudiana Bert.. I. Inducţia calusului şi organogenezei. St. şi Cercet. Șt., Ser. Biol. (Univ. Bacău), 1, Serie nоuă, 9-14.

Ghiorghiță, G., Prisecaru, M., Nicuță, D., \& Stănescu, I. (2000). The morphogenetic reaction of some Stachys sieboldii Miq. explants in in vitro cultures. Rev. Roum. Biol., Ser. Biol. Veget., 45(1), 29-37.

Guha, S., \& Maheshwari, S. C. (1964). In vitro production of embryos from anthers of Datura. Nature, 204, 497.

Horsch, R. B., Fry, J. E., Hoffman, N. L., Eichholz, D. A., Rogers, S. G., \& Fraley, R. T. (1985). A simple and general method for transferring genes into plants. Science, 227(4691), 1229-1231.

Hussain, A., Qarshi, I. A., Nazir, H., \& Ullah, I. (2012). Plant tissue culture: Current status and opportunities. INTECH.

Hussain, S., Fareed, Sh., Ansari, S., Rahman, A., Ahmad, I. Z., \& Saeed, M. (2012). Current aproaches toward production of secondary plant metabolites. J. Pharm. Bioallied Sci., 4(1), 10-20.

Ikeuchi et al. (2017). Wounding triggers callus formation via dynamic hormonal and transcriptional changes. Plant. Physiol., 175(3), 1158-1174.

Ikeuchi, M., Ogawa, Y., Iwase, A., \& Sugimoto, K. (2016). Plant regeneration: Cellular origins and molecular mechanisms. Development, 143, 1442-1451.

Ikeuchi, M., Sugimoto, K., \& Iwase, A. (2013). Plant callus: Mechanisms of induction and repression. Plant Cell, 25(9), 3159-3173.

Jain, S. M. (2001). Tissue culture-derived variation in crop improvement. Euphytica, 118, 153-166.

Janarthanam, B., Gopalakrishnan, M., \& Sekar, T. (2010). Secondary metabolic production in callus cultures of Stevia rebaudiana Bertoni. Bangladesh J. Sci. Ind. Res., 45(3), 243-248.

Jiménez, M. V. (2001). Regulation of in vitro somatic embryogenesis with emphasis of the role of endogenous hormones. R. Bras. Fisiol. Veg., 13(2), 196-223.

Karuppusamy, S. (2009). A review on trends in production of secondary metabolites from higher plants by in vitro tissue, organ and cell cultures. J. Med. Plants Res., 3(13), 1222-1239.

Kumar, P. (n. d.). Contribution of eminent scientists towards plant tissue culture. Retrieved from $\mathrm{http} / / / \mathrm{www}$. biologydisscusion.com/plant-tissue-culture/contribution-of-eminent-scientists-towards-plant-tis sue-culture/11849

Kumar, S. (a). Callus tissue: Morphology, internal structure and characteristics. Retrieved from http://www.biologydiscussion.com/plant-tissues/callus-tissue-morphology-internal-structure-and-characteri stics-with-diagram/14591 
Kumar, S. (b). Callus Culture: History, Principles and Significance. Retrieved from http://www.biologydiscussion.com/plant-tissues/callus-culture/callus-culture-history-principles-and-signific ance-plant-tissue-culture/14597

Larkin, P. J., \& Scowcroft, W. R. (1981). Somaclonal variation-a novel source of variability from cell cultures for plant improvement. Theor. Appl. Genet., 60(4), 197-214.

Lee, M., \& Phillips, R. L. (1988). The chromosomal basis of somaclonal variation. Ann. Rev. Plant Physiol. Plant Mol. Biol., 39, 413-437.

Maftei, D. E. (2013). Cultura in vitro la plante aromatice. Edit. "Alma Mater". Bacău, 239.

Maftei, D. E., Ghiorghiță, G., \& Nicuță, D. (2006). Considerations regarding the in vitro behaviour of basil (Ocimum basilicum L.). An. Şt. Univ. “Al. I. Cuza” Iaşi, Ser. Genetică şi Biol. Mol., 7(1), 151-157.

Margara, J. (1982). Bases de la multiplication vegetative: les méristèmes et l'organogenèse (p. 262). Ed. INRA, Paris.

Mathur, A., Mathur, A. K., \& Gangwar, A. (2000). Saponin production by cell/callus cultures of Panax species. Proceed. Phytochem. Soc. of Europe, 45, 171-179. Springer, Dordrecht.

Mathur, A., Shukla, Y. N., Pal, M., Ahuja, P. S., \& Uniyal, G. C. (1994). Saponin production in callus and cell suspension cultures of Panax quinquefolium. Phytochemistry., 35(5), 1221-1225.

Melchers, G., Sacristan, M. D., \& Holder, A. A. (1978). Somatic hybrid plants of potato and tomato regenerated from fused protoplasts. Carlsberg Res. Communications, 43(4), 203-218.

Miller, C., Skoog, F., Von Saltza, M. H., \& Strong, F. M. (1955). Kinetin, a cell division factor from desoxyribonucleic acid. J. Am. Chem. Soc., 77(5), 1392.

Molina, M. C., \& Garcia, M. D. (1998). Analysis of genetic variability in long-term callus cultures and regenerated plants maize. Cytologia, 63, 183-190.

Morel, G., \& Martin, C. (1952). Guerison de dahlias atteints d' une maladie a virus. C. R. de l'Acad. Sci., Paris, 235, 1324-1325.

Murashige, T., \& Skoog, F. (1962). A revised medium for rapid growth and bio assays with tobacco tissue cultures. Physiol. Plant., 15(3), 473-497.

Nicuță, D., \& Ghiorghiță, G. (2010). Studies on the in vitro behaviour of the ovaries of Brassica oleracea var. botrytis. Studii și cercet. șt., Ser. Biol. Veget. (Univ. Bacau), 18, 86-92.

Nicuță, D., \& Ghiorghiță, G. (2019). Androgeneza și ginogeneza experimentală la unele specii de Brassica. Edit. "Alma Mater", Univ. "V. Alecsandri”. Bacău, 158.

Nicuță, D., Ghiorghiță, G., \& Maftei, D. E. (2011). Aspects of in vitro cultures of ovaries at Brassica juncea Czern. Studii şi cercet. Şt., Ser. Biol. Veget., (Univ. Bacau), 20(1), 32-37.

Nicuță, D., Ghiorghiță, G., \& Maftei, D. E. (2012). Cytogenetic observations on some in vitro regenerants provided by ovaries of Brassica oleracea var. capitata. An. Şt. Univ. "Al. I. Cuza”, Iaşi, s.II-a, Biol. Veget., $58(2), 31-46$.

Nicuță, D., Ghiorghiță, I. G., \& Mihu, G. (2003). The morphogenetic reaction of anthers and ovaries in in vitro cultures of Brassica oleracea L. An. șt. Univ. Craiova, 8, 227-231.

Noé, A. C. (1934). Gottlieb Haberlandt. Plant Physiology, 9(4), 850-855.

Novák, F. J. (1980). Phenotype and cytological status of plants regenerated from callus cultures of Allium sativum L. Zeitschrift fur Pflanzenzuchtung, 84(3), 250-260.

Novák, F. J. (1981). Chromosomal characteristics of long-term callus cultures of Allium sativum L. Cytologia, 46, 371-379.

Phillips, C. G. (2004). Invited review: In vitro morphogenesis in plants - recent advances. In vitro Cell. Dev. Biol.Plant, 342-345.

Polanco, M. C., Peláez, M. I., \& Ruiz, M. L. (1988). Factors affecting callus and shoot formation from in vitro cultures of Lens culinaris Medik. Plant Cell and Organ Culture, 15(2), 175-182.

Prisecaru, M., \& Ghiorghiță, G. (2002). Haploidia experimentală în contextul biotehnologiilor moderne. Edit. Tehnică. Bucureşti, 192. 
Prisecaru, M., Ghiorghiță, G., Iliescu, C., \& Petrescu, D. (1995). Studiul organogenezei in vitro la Rosmarinus officinalis L. Lucr. Simp. Nat. Farm. "Actualităţi şi perspective în cercetarea medicamentului". Iaşi, 27-28.

Rai, R. (2007). Genetics and plant breeding. Introduction to plant biotechnology. Retrieved from http://nsdl.niscair.res.in/jspui/bitstream/123456789/668/1/revised\%20introduction\%20to\%20plant\%20biote chnology.pdf

Reddy, A. S., Sita, P., Devi, P. S., \& Kiran, S. R. (2013). In vitro celle culture of Charybdis congesta for enhanced production of secondary metabolites: Prosillaridin A., scillaren A and scilliroside. African J. Biotechnol., 12(15), 1754-1759.

Rout, G. R., Mohapatra, A., \& Mohan, J. S. (2006). Tissue culture of ornamental pot plant: A critical review on present scenario and future prospects. Biotechnology Advances, 24, 531-560.

Skoog, F., \& Mille, C. O. (1957). Chemical regulation of growth and organ formation in plant tissue cultures in vitro. Symp. Soc. Exp. Biol., 11, 118-131.

Sunderland, N. (1973). Nuclear cytology. In H. E. Street (Ed.), Plant Tissue and Cell Culture. Blackwell Sci. Publ., Oxford, 161-190.

Sussex, M. I. (2008). The scientific roots of modern plant biotechnology. Plant Cell, 20(5), 1189-1198.

Tavakkol-Afshari, R., Angoshtari, R., \& Kalantari, S. (2011). Effects of light and growth regulators on induction of callus growth in rapeseed (Brassica napus L.) genotypes. Plant Omics J., 4(2), 60-67.

Thorpe, A. T. (2007). History of plant tissue culture. Mol. Biotechnol., 37(2), 169-180.

Toma, C., Toma, I., \& Ghiorghiță, G. (2005). Morphogenetical and histological data about Salvia officinalis cultivated in vitro. Europ. J. Drug Metabolism and pharmacokinetics, 30, 43-44.

Udomsuka, L., Jarukamjorna, K., Tanakab, H., \& Putaluna, W. (2009). Production of isoflavonoids in callus cultures of Pueraria candollei var. mirifica. Z. Naturforsch., 64c, 239-243.

Vaishnava, A. (2017). History of plant tissue culture. Retrieved from http:/www.sciencebeing.com/2014/03/history-of-plant-tissue-culture/

Vanisree, M., Lee, C. Y., Lo, S. F., Nalawade, S. M., Lin, C. Y., \& Tsay, H. S. (2004). Studies on the production of some important secondary metabolites from medicinal plants by plant tissue cultures. Bot. Bull. Acad. Sin., 45, $1-22$.

Verma, A. K., Singh, R., \& Singh, S. (2012). Improved alkaloid content in callus culture of Catharanthus roseus. Bot. Serbica, 36(2), 123-130.

Verma, S. K., Das, A. K., Cingoz, G. S., Uslu, E., \& Gurel, E. (2016). Influence of nutrient media on callus induction, somatic embryogenesis and plant regeneration in selected Turkish crocus species. Biotechnol. Rep., $10,66-74$.

Yue, W., Ming, Q., Lin, B., Rahman, K., Zheng, C. J., Han, T., \& Qin, L. (2014). Medicinal plant cell suspension cultures:pharmaceutical applications and high-yielding strategies for the desired secondary metabolites. Critical Rev. Biotechnol., 36(2), 1-18.

Zimmerman, J. L. (1993). Somatic embryogenesis: A model for early development in higher plants. The Plant Cell, $5,1411-1423$.

\section{Copyrights}

Copyright for this article is retained by the author(s), with first publication rights granted to the journal.

This is an open-access article distributed under the terms and conditions of the Creative Commons Attribution license (http://creativecommons.org/licenses/by/4.0/). 